\title{
INDIVIDUAL VIEWS AND SHARED LANDSCAPES OF FOLKLORE IN REYKHOLTSDAL, ICELAND
}

\author{
Laura Puolamäki ${ }^{1}$
}

Received 9 June 2011; Accepted 23 March 2012

\begin{abstract}
This paper examines the different views about the cultural landscape that local people and experts have, and explores the ways in which these two perceptions could be merged. The empirical data were collected during a Nordic PhD course in Iceland. It gives a glimpse to an invisible landscape of folklore in the surroundings of the Reykholt village. The village was founded in the twelfth century. Local folklore has evolved alongside with cultural landscape, and it has a strong impact on local landscape perception. Different types of cultural heritage features, like churches and industrial buildings, are connotations of social and cultural codes through which we participate in our environment. In Reykholtsdal intangible cultural heritage is attached to the natural features in the landscape. Those features are similar codes to local people as those we are used to see in the built environment. Both local people and experts have knowledge about the cultural landscape. Local people usually have practical knowledge which is based on perceptions and experiences. Experts have scientifically validated knowledge, which can be deepened with perceptions and experiences. Both the information is significant, when cultural landscape is evaluated based on landscape definition by the European Landscape Convention. We would need new practices for inventory of perceived landscape. They would not only help us to meet aims of landscape policies set in the European Landscape Convention (Council of Europe: 2000), but also to protect the intangible cultural heritage attached to landscape as defined by UNESCO (World Heritage Convention: 1972, Convention for the safeguarding of Intangible Cultural Heritage: 2003). New inventory methods could also help us to find shared values through which we could evaluate and manage a landscape.
\end{abstract}

Key words: cultural heritage, landscape perception, evaluation, cultural identity, shared landscape values

Yhteenveto: Tämä artikkeli tarkastelee erilaisia näkökulmia maisemaan ja etsii tapoja niiden yhteensovittamiseksi. Paikallisen tiedon ja asiantuntijatiedon yhdistäminen ja sen kautta maiseman tarjoaman kulttuuri-identiteetin vahvistaminen edistäisi maiseman kestävää käyttöä. Empiirinen aineisto on kerätty pohjoismaisen jatko-opiskelijoiden kurssin yhteydessä. Se tarjoaa välähdyksen Reykholtin kylän ympäristöä näyttämönään käyttävään näkymättömään maisemaan. Keskiajalla perustetun kylän kansanperinne on kehittynyt yhdessä kulttuurimaiseman kanssa, ja sillä on voimakas

\footnotetext{
${ }^{1}$ Laura Puolamäki MA, PhD student, University of Turku, Degree program in Cultural pruduction and Landscape Studies, P.O. Box 124 FI -28101 Pori llpuol@utu.fi
} 
vaikutus paikalliseen tapaan havainnoida maisemaa. Asiantuntijoiden menetelmät inventoida ja arvottaa kulttuurimaisemaa eivät tunnista tätä aineetonta kulttuuriperintöä, vaikka se on luonteestaan huolimatta nykyaikainen tekijä maiseman dynamiikassa. Olemme tottuneet liittämään aineettoman kulttuuriperinnön maisemassa rakeenttuun ympäristöön. Reykholtin kylän maisemassa se liittyy ensisijaisesti luonnonympäristöön. Tarvitsemme uudenlaisia menetelmiä havaitun maiseman inventoimiseksi, jotta voimme vastata niin Euroopalaisen maisemayleissopimuksen kuin UNESCONkin esittämiin haasteisiin liittyen kulttuuriympäristöihin. Uudenlaiset menetelmät voisivat edistää jaettujen maisemaarvojen löytämistä ja niiden käyttämistä maiseman arvottamisessa ja hoidossa.

\section{Introduction}

Landscapes can have many faces. Moreover, landscapes can be evaluated in a number of different ways. Experts often view them from documents and measurable data, while nonexperts' opinions are driven by intuition and inherited knowledge landmarks built out of memories, experiences, beliefs and social boundaries.

The European Landscape Convention (later ELC) highlighted lived landscape, perception of belonging and cultural identity (Council of Europe: 2000, Brunetta \& Voghera: 2008 p. 73). Identifying shared values of individual people as well as groups is a central matter if we want to meet aims set in the ELC.

The empirical data of this case study was collected in Iceland in August 2009 during a Nordic PhD course of NOVA University Network organized by Norwegian University of Life Sciences. The study group had five members from Finland, Sweden and Norway, one Swedish member was born in Iceland. The study group collected the data and composed a report. In this article the field findings from the PhD course are used as a starting point for further discussion.

The folkloristic tradition in Iceland is vibrant. In this case study the aim was to learn, how peoples' way to read the landscape through folklore impacts their way to perceive and to use the landscape.

A combination of photographs, semi-structured interviews and expert data were used to catch the local peoples' way to comprehend the landscape in Reykholtsdal.

The Krogh's Model for Landscape Comprehension (2008) was used to interpret the results from field data.

In Reykholtsdal intangible cultural heritage related to folklore is still a modern factor. It sometimes steers land use and it has both private and public nature. The social and cultural codes that guide peoples' way to participate in the environment are usually attached to cultural features in the landscape. In Reykholtsdal, when landscape is read through folklore, they are attached to natural features of the landscape.

In this case study the inventory of perceived landscape revealed unpredictable shared landscape values. The visible natural features in the landscape are covered with invisible cultural layers. Inventory of such landscape perception needs new kind of methods of identification. Implementing of such landscape values, which are actually meanings, into landscape policies requires fresh methods as well.

\section{The Landscape of Reykholtsdal}

\subsection{Research area}

Research area is located in the western part of Iceland. Reykholt village and its surroundings have been settled since the middle ages. The famous sagas, like Eddas, Heimskringla and Egil were written in Reykholt by Snorri Sturluson, the medieval chieftain and poet. 
The settlers of Iceland have maintained that mystic relationship to nature, which has disappeared from other Nordic countries almost completely. In folklore the common landscape is full of various creatures, like trolls and fairies. They live for example in rocks, hills and lakes, and are visible to some people if they decide to be. They are believed to descend from some of the children of Adam and Eve. When God visited Adam and Eve, he wanted to meet their children, too. Those children were like any other children, dirty after playing outside. Eve had not enough time to wash all the children before God's visit, so she decided to hide the unwashed ones. God saw that, and said that whatever is hidden from God's eyes, shall be hidden from people as well. That's why they are hidden people, visible only when they want to be seen. (Hallmundsson \& Hallmundsson, 2009 p. 14)

Sagas did not describe these folk stories about landscape. They have wandered through generations, being passed on as bedtime stories when mother puts her children to sleep or when father teaches his son the landmarks of the estate.

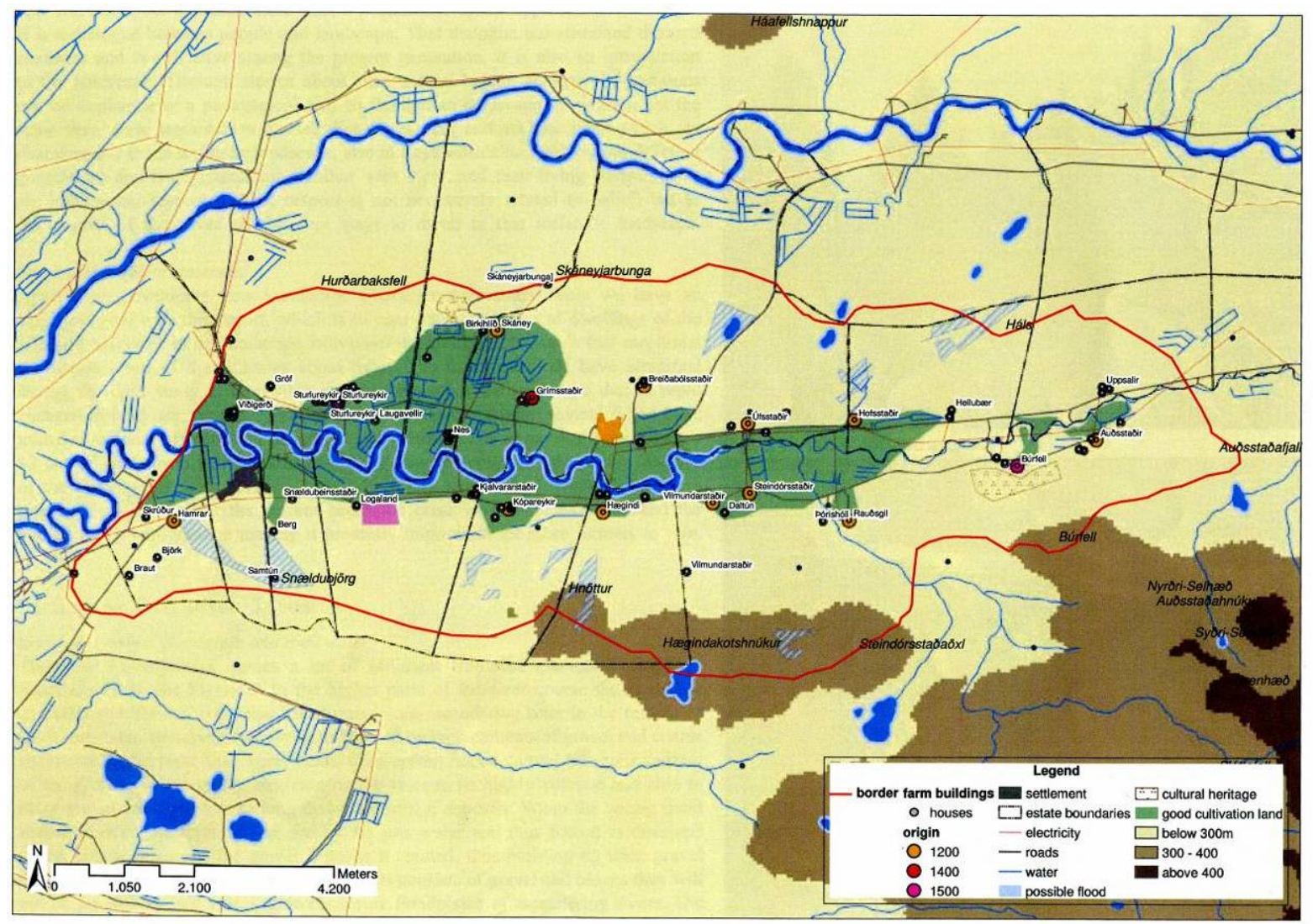

Fig 1. Research area in Reykholtsdal. Map: R. Aradi 2009

The valley is bounded by hills, rising up to 300 metres. The river which runs through the valley, Reykjadalsá, begins from the glaciers Eiriksjökull and Langjökull. South of the river there are vertical rock walls, while in the north there is a hill zone. The hills are undulating with outcrops which form typical post-glacial abrasion forms, with a soft abraded side in the direction of the ice flow and a lee side against the direction of ice flow, untouched by glacial abrasion (Aradi et al., 2009).

Since the end of the latest ice age Betula pubescens has formed extensive forests. Due to the arrival of humans, the native Icelandic ecosystems have radically changed. The introduction of grazing animals has in many places led to land degradation and soil erosion. (Aradottir, 2005 p. 67-68)

Early settlement in Reykholtsdal began with chieftain Skallagrimur. There are 36 estates in Reykholtsdal. Almost half of them were founded in the twelfth century, 17 of them were founded by the end of fifteenth century. 19 estates are founded later, mostly in years 1934 and 1935 (Sveinbjarnadottir et al., 2008 p. 4). 
After the recession in 1930's the government encouraged farmers to parcel their land to establish new farms. Parcelling did not fracture the landscape, and the settlements medieval structure can still be easily seen. The latest parcelling started in 1990's when farmers started to sell land to cottage owners (Gudrasson, 2009). Such areas are locally called cottage fields. In Reykholtsdal, the cottages are situated at the northern hill zone.

The cultural landscape of Reykholtsdal has sustained through centuries. The residents have earned their living from the land in medieval times, and they still do. Only the methods have evolved, and the landscape is evolving along with them. In the riverbed hay making has changed into effective fodder production, and white plastic-rolled hay bales are as usual in Reykholtsdal as in any other village in the European countryside. In the hill zone sheep grazing is changing to forestry and open slopes are getting covered with woods again. New species are introduced to achieve more effective timber production, and at the same time new landscape is introduced as well. In the center of the village, where Snorri Sturluson collected the local stories and wrote the sagas, the collection of cultural heritage is now changing to cultural production.

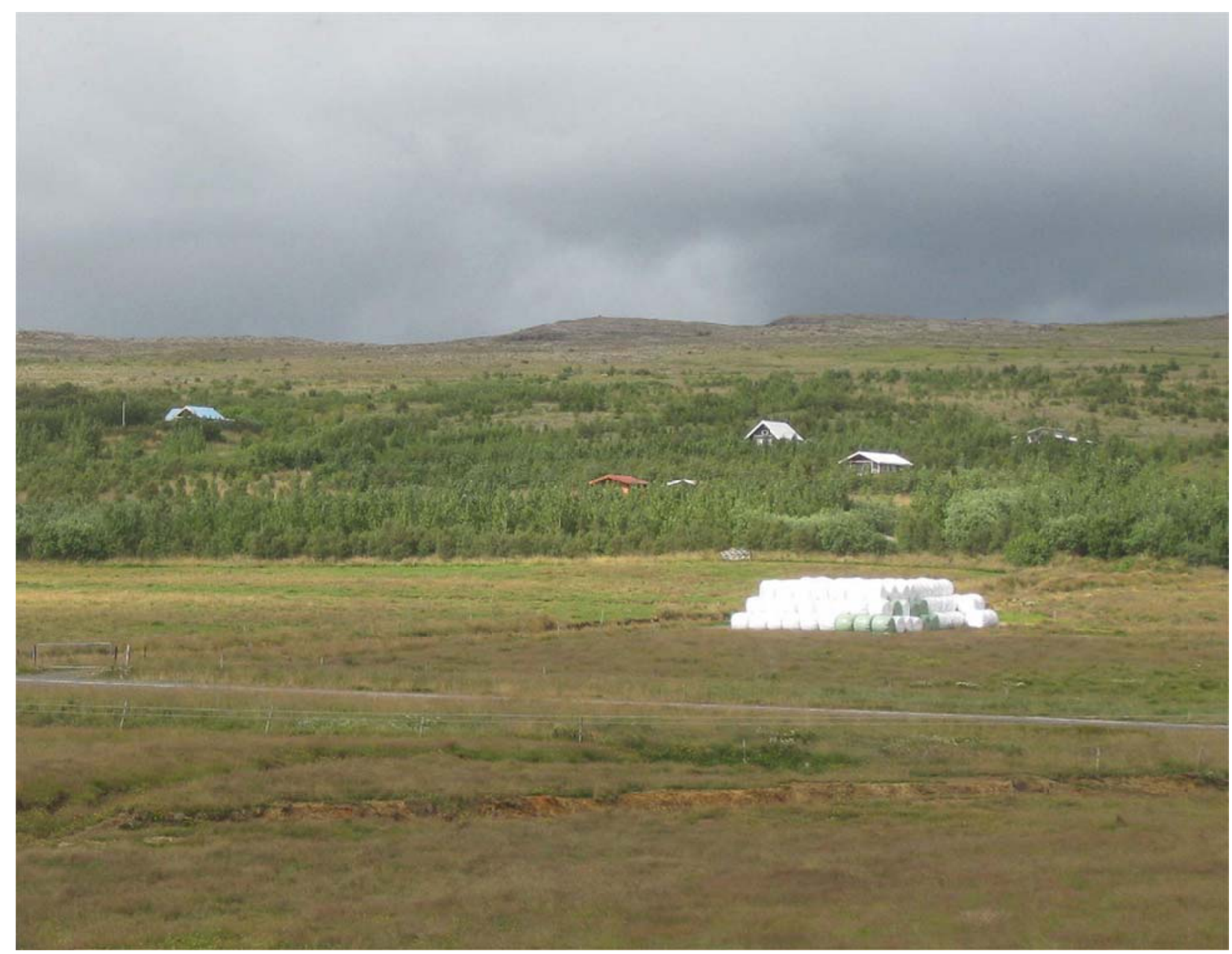

Fig 2. Cottage field in Reykholtsdal. Landscape in the northern hill zone is changing due to afforestation. Ecologically it is reasonable to restore the soil coverage. Culturally it causes conflicts. Many people think that the Icelandic landscape should be open and land forms should be visible. Photo: L. Puolamäki 2009 


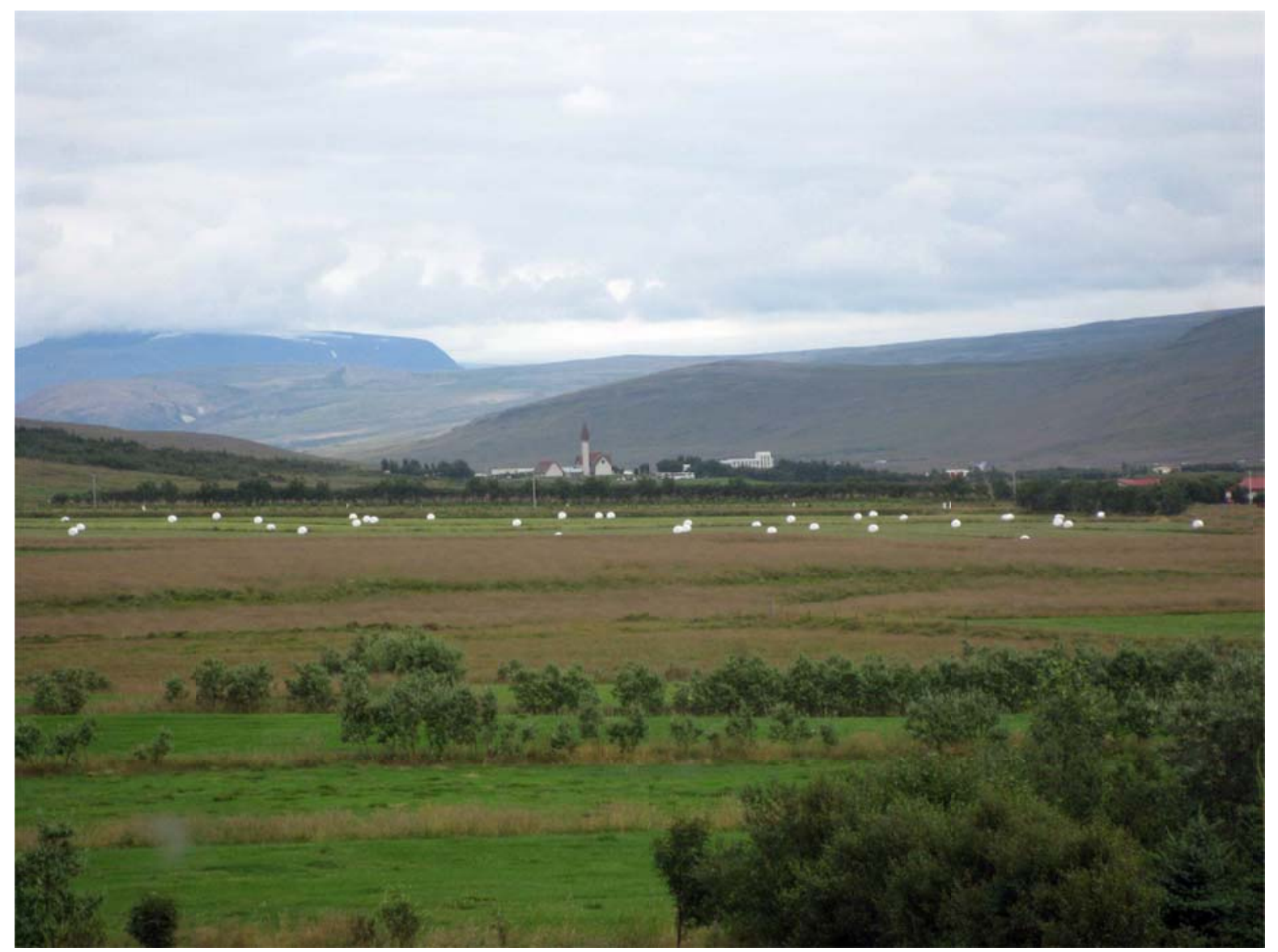

Fig 3. The cultural landscape of Reykholtsdal. Photo: L. Puolamäki 2009

\subsection{Methods}

Understanding landscape based on individual perceptions raises a question about how to recognize and comprehend the common features beginning from various interpretations. Decoding the perceived landscape demands a dialogue between the individuals, the researcher and planner. Cristina Mattiucci has developed a method called Kaleidoscope and tested it in Roncegno, Italy. The Kaleidoscope model evaluates ordinary landscapes of ordinary people. Kaleidoscope combines interviews and photowalks in order to open one's personal landscape experience and perception to an outsider. During the walks informants take pictures from the landscapes they see as important. The facilitator interviews the informants during the walk to get a holistic view of their landscape preferences (Mattiucci, 2010 p. 40-45). In Reykholtsdal quite similar method was applied.

The expert data from GIS files and published sources about the landscape was reviewed to catch the expert view of Reykholtdal and compared it to the local one. The data about the cultural factors was collected from historical maps and a research article about the settlement (Sveinbjarnardóttir et al., 2008).

Then the local folklore landscape was traced by semi-structured interviews and a method called photomodelling.

According to some stories elfs and hidden people have reserved places in the landscape for different uses. Low, grassy hills are sometimes used for grazing and haymaking. Weathering cliff, solid rock or vertical rock wall can be a habitat of elfs and hidden people. Examples of such formations were identified from the landscape, partially outside the study area, and photographed. Two random views, with no expected relation to folklore and landscape, were also photographed.

Several "kitchen-table" interviews were arranged with the informants, at their homes and offices. They were not taken for a walk, as in Mattiucci's Kaleidoscope model, Instead they were taken 
to a tour in the valley by showing the photographs and interviewing the informants to get a holistic view of their landscape perception regarding folklore.

The informants were local experts and lay people, The total number of informants was 12 . First the key informants were identified and interviewed to learn how the land use is planned and how the field data of experts is collected. They were municipality planning officer, forestry officer and the director of Medieval Center. The key informants suggested other informants, and eventually they were found with snowball-method. Some random information was also collected by simply going to peoples' doorsteps.

Three informants were local people, who work in the village at Snorrastofa center and Foss Hotel. Five informants were farmers from different parts of the valley. Two were cottage owners, who live in Reykjavik and two were experts who work in the area.

The aim of the interviews was to identify individual physical elements of the folklore present in the landscape. The aim was also to identify relation between narrative landscape and actual land use.

First all the informants were asked about their thoughts and plans about the land. Second question was if they knew anything about the local folklore and hidden people. Third they were shown a series of photographs about those geological formations which are possible dwellings of hidden people, and asked to explain what they saw in the photograph.

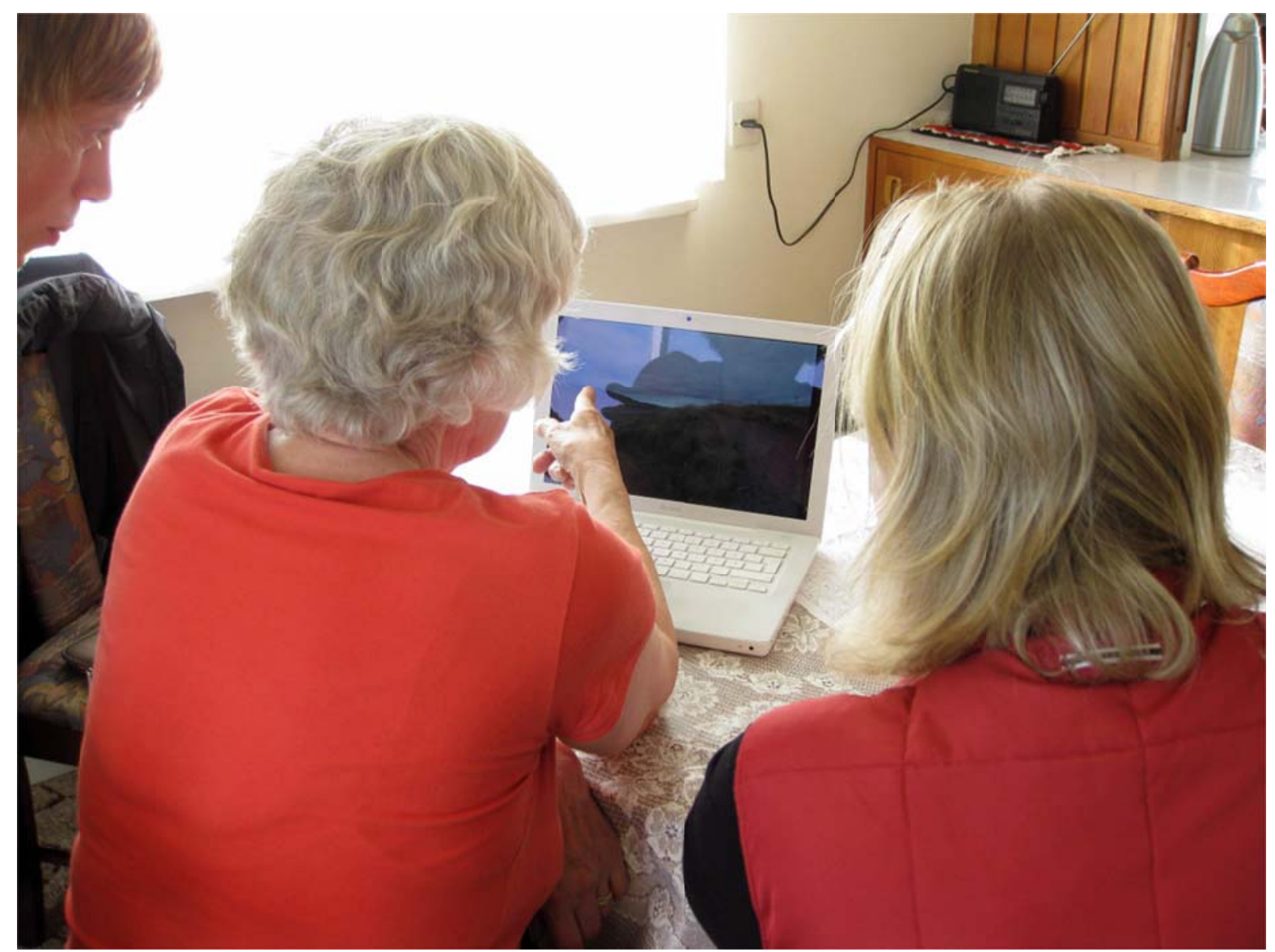

Fig 4. Kitchen-table interview in Grof farm. Enchanted landscape is a very common phenomenon in Iceland, but also very personal. It is possible to trace the land forms that are typical to them, and use them as indicators while tracing the local folklore. But to catch the local peoples' landscape perception it is essential to get acquainted with their way to read the landscape. Folklore landscape can be personal, a family tradition or collective. Photo: L. Puolamäki 2009 


\subsection{Research theory}

The model for landscape comprehension (Krogh et al., 2008) is used as a theoretical background of the relationship between people and landscape for interpreting the findings from the case study.

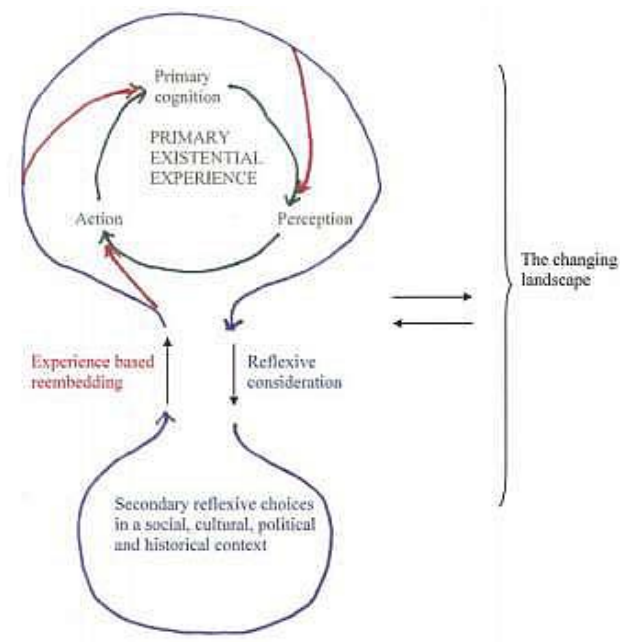

Fig 5. Model for Landscape Comprehension. Krogh et al., 2008

We read and revise the landscape constantly through a unification of perception, cognition and action (Krohg et al., 2008, p. 22). Our relationship to landscape is intuitive, even for those of us who do not have a mystic relationship to landscape.

In traditional theories, like Carl Sauer's, landscape is a cultural whole, which has developed from the nature by the action of some cultural group. In this process culture is an agent, which launches the change in landscape. Natural landscape is a mediator in this process. The product is a cultural landscape, a landscape with visually observable traces of human activity (Wylie, 2008 p. 20). The expert's task is usually to observe and evaluate those traces.

ELC brought lived landscape, an approach and evaluation based on personal landscape experiences, to the discussion of the experts and authorities (Council of Europe, 2000). Places of high value to the locals are often missing from experts' inventories and evaluations.

When we make plans for cultural landscapes by the landscape definition of ELC, we have to go further than the visible landscape to reach the landscape scale level. A central purpose of landscape scale planning is to capitalise on the ways in which people attach to and identity with a place, thereby building capacity for creative participation (Selman, 2006 p. 110).

Human perception of belonging and of cultural identity is central to the ELC's notion of landscape. It is not enough to protect and improve the material signs of the past. Instead, we should 'identify' the landscape by recognizing what the peoples' shared landscape values. (Brunetta \& Voghera, 2008 p. 74).

Haapala (2000) has discussed environmental ethics and environmental aesthetics concerning the evaluation of nature. His argumentation can be used also to discuss about evaluation of cultural landscape.

On the other hand Haapala refers to Hepburn (1998), Brady (1998) and Rolston (1998) in his essay. Cognitive conception denudes the landscape of different tones of cultural heritage, and leaves only the visible traces of human actions as the values for further evaluation. On the other hand, it also deepens our aesthetic experience of the landscape by increasing our knowledge. Non-cognitive conception builds knowledge from experiences and intuitive associations, with no requirements of scientific validation.

Landscape includes both tangible and intangible cultural heritage.

In UNESCO World Heritage Convention (1972) natural and cultural heritage is divided into six categories. They include monuments, groups of buildings, sites, natural features, geological and 
physiographical formations and natural sites. These categories refer to tangible cultural heritage.

UNESCO has defined in Convention for the Safeguarding of Intangible Cultural Heritage (2003) intangible cultural heritage as

"the practices, representations, expressions, knowledge, skills - as well as the instruments, objects, artefacts and cultural spaces associated therewith - that communities, groups and, in some cases, individuals recognize as part of their cultural heritage. This intangible cultural heritage, transmitted from generation to generation, is constantly recreated by communities and groups in response to their environment, their interaction with nature and their history, and provides them with a sense of identity and continuity, thus promoting respect for cultural diversity and human creativity".

People are aesthetically engaged with their environment. They are organic, conscious and social organisms, spectators and factors at the same time. In the field of phenomenology and aesthetics the relationship between human and environment has been defined in three stages. The deepest stage is participatory model of environmental experience (Berleant, 1991, p. 8991). These models correspond well to notion of landscape in the ELC.

Landscape is a cultural heritage site, but also an everyday environment, which is continuously moving and changing. Shared landscape values can survive that change, and even construct new values without fossilizing the cultural landscape when human-environment relationship deepens into holistic participation (El Harouny, 2008 p.151-154).

\subsection{Analysis}

Multiple evaluation processes are running in Reykholtsdal all the time. Modern economics and old traditions steer the land use. Some of the processes can be stated from the documents of the authorities, like afforestation plans or land use plans. Some processes are intuitive and based on personal landscape experiences.

Folklore, modern agriculture and rural tourism are in dynamic interaction in Reykholtsdal. For example one of the informants has turned his farm from sheep breeding into fodder production for Icelandic horses and golf course for tourists. The same farmer pointed out an elf rock, where he used to go as a little boy in the northern hills. (Gudrasson, 2009).

\subsubsection{Expert view}

The cultural landscape in Reykholtsdal has developed along with clearance of forests and grazing. Folklore is attached to open landscape and geological landforms exposed due to such land use. For 800 years the Icelanders have been living in this valley, keeping the folklore alive in the landscape by naming inanimated objects (rocks, stones, grassy hills) after folkloristic phenomena - such as álfasteinn, álfaborg, According to the national register of place names Örnefnaskrá, the word for álf (elf) and huldu (hidden) appear innately 1,200 times as part of a place name in Iceland when run in the register (Ámundason, 2009).

Local experts were interviewed to get to know how they evaluate the landscape, and to learn if the folklore has any influence in it. In afforestation plans all the archeological sites are protected. Planning is based on published information or field findings when an afforestation plan is composed. In other words, tangible cultural heritage is recognized and acknowledged. Folklore comes up sometimes in discussions between forestry officer and landowners. Folklore might be acknowledged in plans and forestry actions, but it is not recorded in planning documents.

On municipality level the landscape is assessed mainly through geology, hydrology and climate or climate change. Due to climate change, more effective farming and cultivation of barley is expected to take place in floodplains. Intangible cultural heritage is not included, and there is no data about its presence in the landscape.

The medieval centre of Snorrastofa is carrying out research projects about archaeological sites and medieval literature. The published and researched intangible cultural heritage about 
Reykholtsdalur is intertwined around Snorri Sturluson. His texts are well known, and the actual place where he probably collected some of the stories is preserved.

When landscape experts comprehend the cultural landscape in Reykholtsdal, they experience first the physical landscape elements. They also perceive the openness. The experts can read the development of cultural landscape from the visible traces of human activities by observing the landscape. They also know, how the habitation has developed, and which are the homestead farms. The experts' landscape comprehension is based on visible landscape and it adapts Sauer's theory of cultural landscape as a development process from natural landscape to cultural landscape. (Wylie, 2008 p. 20).

Although the experts' landscape evaluation is based on observable elements and denuded of different tones of cultural heritage (Haapala, 2002 p. 71-72), they can still have very strong aesthetic landscape experience. This experience comprehends from their deep expert knowledge about the processes in the landscape and from their ability to predict and influence to the future landscape. As Haapala notes, knowledge enables pure environmental experience. It also enables participative aesthetic environmental experience, where participation occurs through land use planning (Berleant, 1991, p. 89-91).

When an expert reflects his landscape perception in planning process, he might consider openness as a valuable cultural landscape, overgrazed slope or potential forest, regarding the place name, land owner or soil.

When expert embeds these reflections to his primary experiences, he might recommend settlement, erosion control or afforestation. These actions are based on careful evaluation, and they aim to protect both natural and cultural values in the landscape. But they are sectorized values, not shared with community. They represent the perception of belonging and cultural identity of experts, who experience the landscape through scientific and cognitive conception.

\subsubsection{Peoples'view}

The local people were interviewed the same way than the experts. The aim was to know, how they evaluate the landscape and if folklore has any influence on it.

The photographs featuring the valley produced various interpretations. To some of the informants there was a typical landscape, good cultivation land or a place to pass every day. To some informants some of the places were possible dwellings of hidden people, but they explained very carefully why all the places we not suitable. For example a loose rock would not do, it has to be solid. Hidden people also like open space and landscape, and when the habitat is a rock formation, it has to be in a tranquil place.

One informant, who recognized a low hill at the gate of a Sturly-Reykir farm, told that one of the other low hills in the village used to be a place where they lit a bonfire at the New Year's Eve. The hill was called Kastali. It turned out to be enchanted, and a series of accidents happened until they removed the bonfire to another place (Emilsdottir, 2009).

Non-cognitive conception does not require any scientific knowledge about the environment in order to offer aesthetic experience. It allows the observer to imagine and to associate, for example, certain land forms to certain experiences. The informant had experienced accidents at the Kastali. It was a second hill with a similar form in the same village causing accidents when disturbed. After reflexive consideration and experience based reembedding, the residents decided to remove the bonfire. After that, all such hills are possibly enchanted in their primary cognition, until further investigations (Haapala, 2000 p. 69-70).

People may also experience places as possibly enchanted because of their name, not only because of their feature. Further evaluation requires reflective consideration between personal landscape experiences, personal cultural identity and personal environmental relationship. Embedding these choises to primary experiences creates the sence of place. The result may be just a place with a name, a place with a story or enchanted place.

The enchanted landscape has two natures. It can be private, when the intangible cultural heritage related to some place is known only among one family. It can also be collective, when 
the intangible cultural heritage related to some place is known among almost to the whole village. To an observer a folk name is distinctive to these places. They also have common geological forms, which may pay attention. But the enchanted landscape is not stabile.

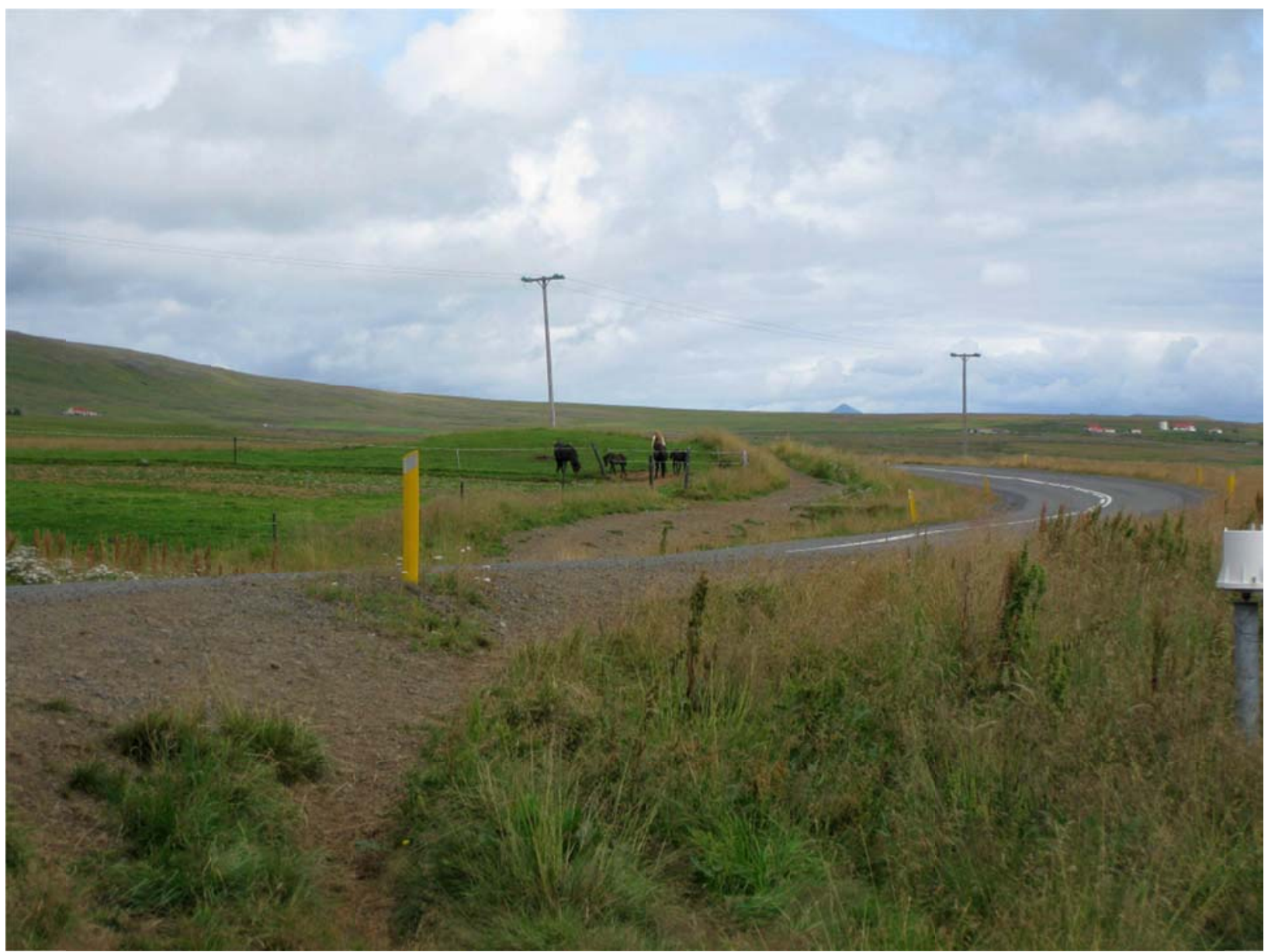

Fig 6. Álagablettur at the gate of Sturly-Reykir farm. The road could be straightened, but it is left to curve around the hill. One of the informants knew the place, but told us that she did not believe in hidden people at all. When she saw this photograph, she still wondered if it is wise to let the horses graze at the hill or to ride across it. Photo: L. Puolamäki 2009

Some enchanted places have been known for long. The present generation may not have any personal experience of them, but the sites are known, sometimes protected or named and at least respected. Some enchanted places are alive only in place names or in memories of a very few people. Some private enchanted places are a heritage from previous owners of the estate. They are shown, when the estate is sold to a new owner, and the present owner has his own experience of enchantment. Some enchanted places are new. They come up, when something happens. Often it is some accident, caused by hidden people when their habitat is interfered. The accidents create a story, known among a family or a village, and the place is left undisturbed from people.

According to Hall (1996) identity is related to the invention of tradition as much as to the tradition itself, and that belongingness through which identities arise, is partly in imagination, and therefore in part based on fantasy.

Folklore landscape includes those shared values (Brunetta \& Voghera, 2008 p. 74) and common features (Mattiucci, 2010 p. 77) which create peoples' perception of belonging and cultural identity. Some of those shared landscape values have survived changes in the cultural landscape. They have also constructed new values and affected to the human-environment relationship (El Harouny, 2008 p. 152). 


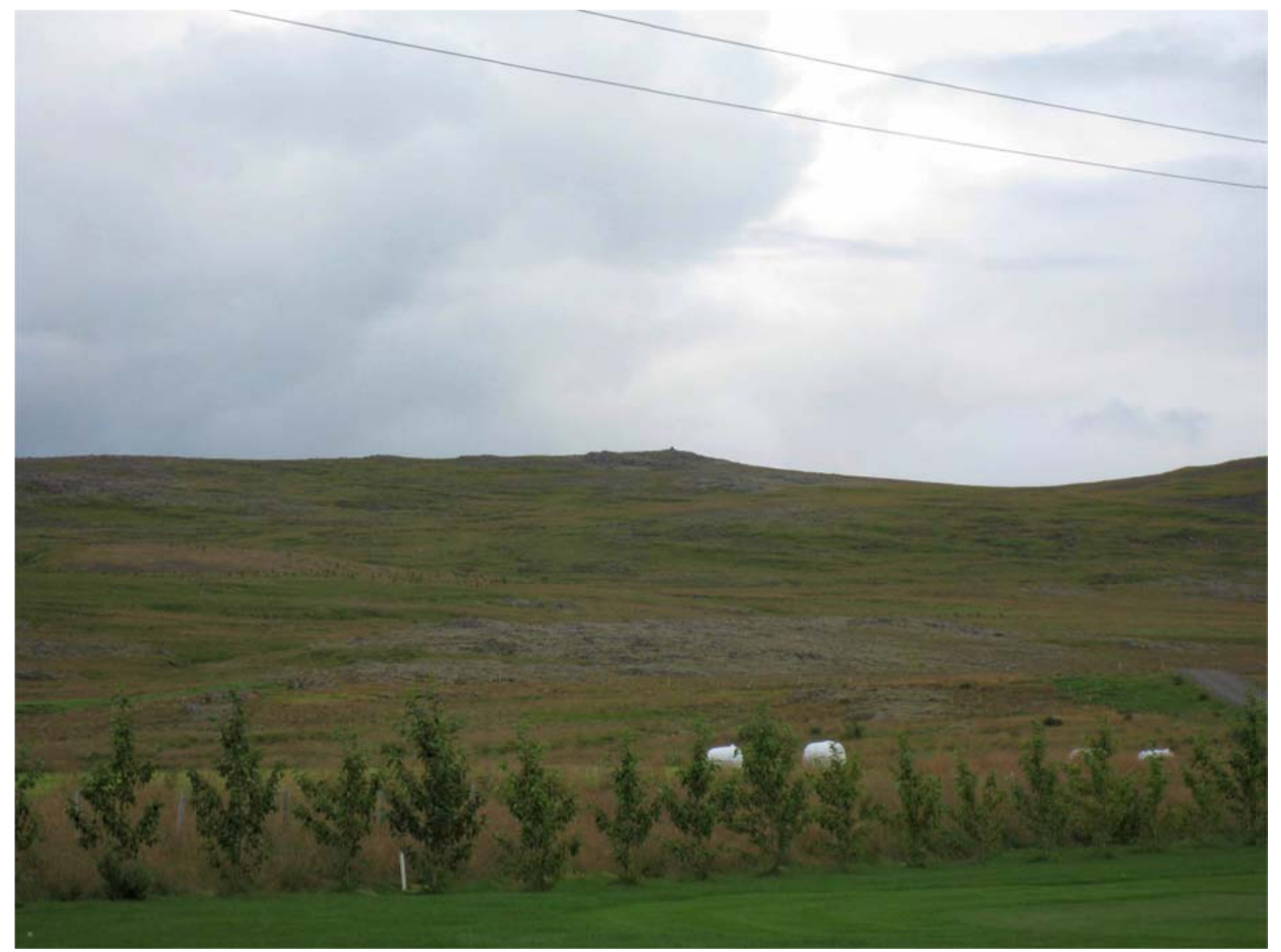

Fig 7. An elf rock up in the northern hills. A golf course for rural tourists, plastic-rolled' hay bales and a private place which is also a shared landscape tradition can all be found in the same photograph. Photo: L. Puolamäki 2009

\subsubsection{Expert data and practical knowledge}

The cultural landscape of Reykholtsdal seemingly has two levels. The official level is composed of expert data. It includes verified information about relics and antiquities, land cover, landforms and land use, hydrology, geology and settlement. It includes also estimations about population growth and climate change, but the estimations are based on scientific facts. The authorized evaluation, conservation and planning concerning the cultural landscape is based on this official level. But there is another level, too.

The unofficial level is composed of beliefs and traditions related to landscape. It includes the enchanted landscape, or folklore landscape, and is ever changing. It does not include such verified information, that experts are searching from statistics, maps or reports. It includes information about the places which are believed to be enchanted, and ways to dwell in such a landscape.

The practical evaluation, conservation and planning concerning the cultural landscape is based on this unofficial level. There are no sign posts in the landscape or grids on a map. Still, certain places are protected, roads are curved and buildings are situated following the order of this practical knowledge of local landscape.

Practical knowledge can be compared to environmental competence. It has perceptual, cognitive, affective, behavioural and personal components. With those components we evaluate, use, feel and cope with the environment, and at the same time learn about it. (Pedersen, 1999 p. 303-308)

There are also some bridges between these two levels. In land of Skáney, an informant pointed out three elf castles in the landscape. Two of these had a name; Gálgi and Reynisstekkur and the third was unnamed (Gudrasson, 2009). These name features are also registered in the Örnafnaskrá (the national place name register) as Austur-gálgi and Reynisstekkkur (Bjarnasson, 1943). 
The national place name register has data about formations of nature connected to folklore, because they are often named after enchanted landscape. But the register lacks GIS database. Therefore this expert information connected to practical knowledge would be easily ignored when land use planning documents are collected. The third place in a land of Skáney has no name, so it would not be found even from the register.

One of the experts, the forester, was balancing skillfully between the levels. He represents expertize, but he also knows the territory and the local people very well. When he visits farms and makes afforestation plans with farmers, he familiarizes himself with folklore landscape, and private nature. It is acknowledged in plans if the farmer wants to keep some sights open. These places are not archived to his office but they are added to his practical knowledge for further use.

There is no established procedure to recognize and place folklore, although it is still a modern factor in landscape dynamics. When estates are sold, the enchanted places are often pointed out to the next owners. It is typical practical knowledge in Reykholtsdalur, impossible to trace without local people.

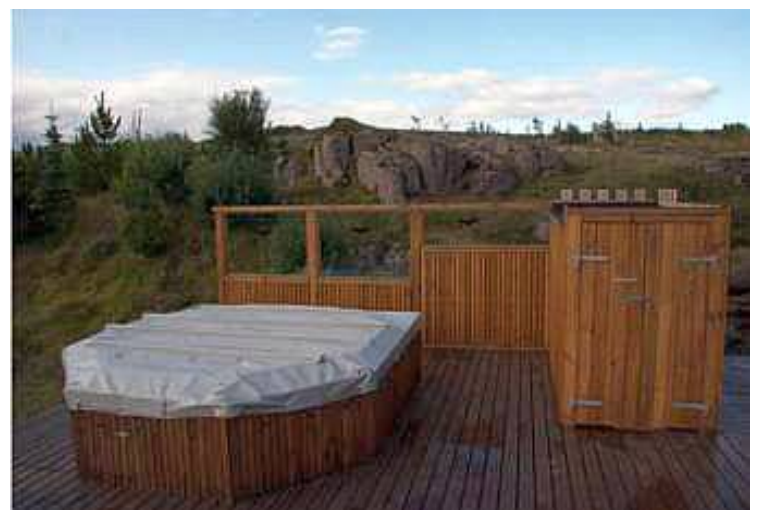

Fig 8. A summer cottage besides an elf queens home. Photo: G. Richnau 2009

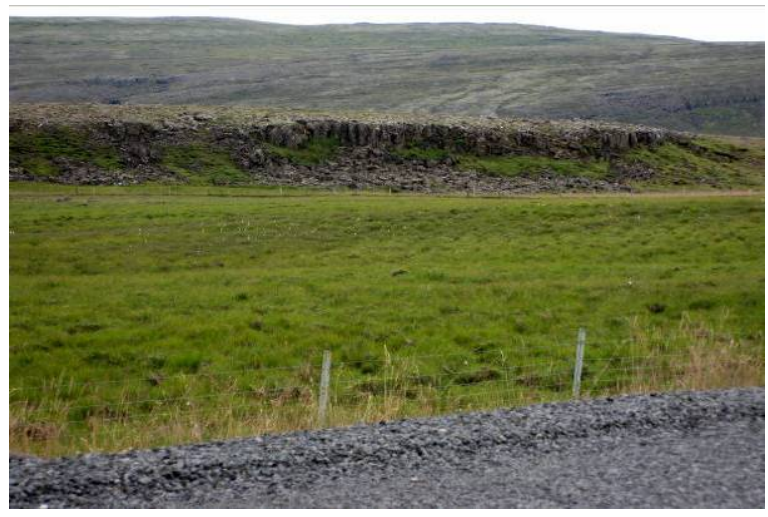

Fig 9. A weathering rock or a piece of local cultural heritage? Photo: L.Puolamäki 2009

In the land of Sturly-Reykir the former landowner told to a couple who built a summer cottage about a midget, named Toki, and an elf queen who had her dwelling just by the place where the house was about to be built. Avoiding disturbing her, the cottage owners decided to build the cottage a few meters away instead. Old foundations that were already laid were used to build a wooden terrace with an outdoor pool and glass by the elf castle to keep the queen's view open to the valley.

Syse (2009) has wondered why the experts do disregard practical knowledge. She highlights Scott's interpretation of the three reasons:

First, doing so reinforces the importance of the experts and their institutions. Second, it is a trait of late modernity to have contempt for history and past knowledge. The scientist or expert is associated with the modern while the farmer or rural labourer is associated with the past, something which modernity will banish. Scientists therefore think they have little to learn from local people. Finally, practical knowledge is represented and codified in a way uncongenial to science. In science, nothing is known until it is proven in a closely controlled experiment (Scott, 1998).

Landscape perception can not be proved or measured in controlled experiment in the way the positivistic science can. Equalizing experts' and non-professionals' view to landscape in land use planning and landscape management may reinforce expert institutions. Folklore is also associated with the past, while planners pursue to associate with the future.

The cultural landscape of Reykholtsdalur can not be divided into the roles of subject and object. We often evaluate visually observable traces of human activity, which differ from the traces of nature activity (Wylie, 2008 p. 20). In Reykholstsdal part of the cultural landscape is adapted 
into the traces of nature activity, those geological formations caused by Iceland's position sitting astride the Mid-Atlantic Ridge.

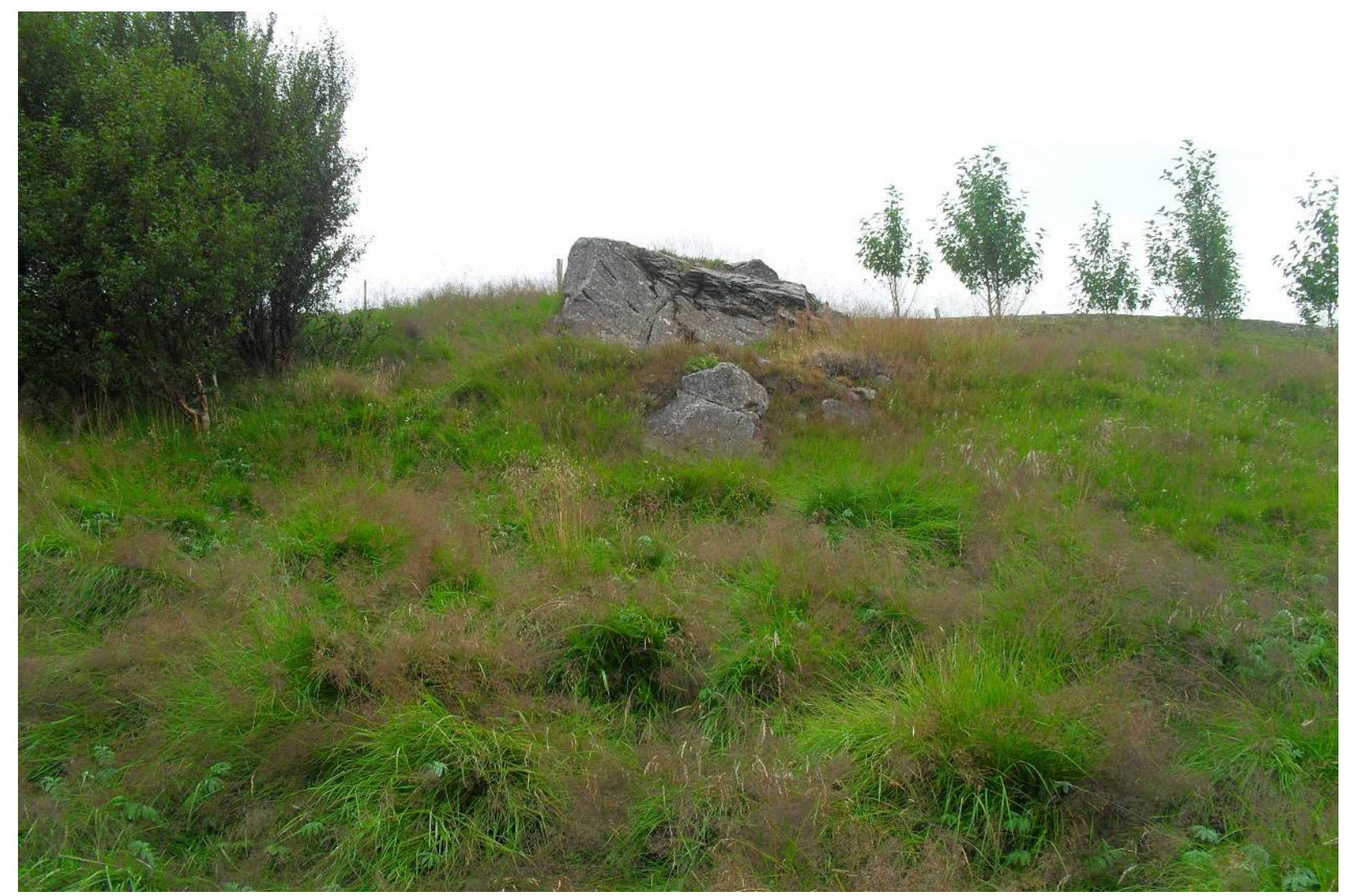

Fig 10. Hulduklettur in the land of Hofstadir farm.

Settling this unique volcanic ground has created unique folklore. Some monuments of culture are visible only to some people. An observer has to be able to see the hidden people, or to know the story about them to find those formations from the landscape which are focal. To many people, lay people as well as experts, they are rock walls, grassy hills, or solid rocks among others. They are an important part of cultural landscape, but they can not be found with general inventory methods.

Sometimes the two levels of cultural landscape meet. Above the farmhouse of Hofstadir there is a rock called Hulduklettur. It is an ancient place of worship and possibly chieftains' homestead. The site is protected and archaeological excavations will take place in near future. The place is also known as a living environment of hidden people. Grazed field and open landscape locates the ungrazed site from the long distance because it is covered from animals with a fence. That is not because of modern protection but because of old tradition in that farm. The farmer does not really believe in hidden people, but he maintains the farming habit he learned from his father. Therefore the next generation will also be familiar both with the artefact and the story.

\section{Holistic landscape interpretation}

Because people are engaged with the environment, our environmental experiences are always participative in some level. In cognitive conception full aesthetic experience requires scientific foundation, to which we can layer our perceptions. In non-cognitive conception aesthetic experience requires only existence and perception (Haapala, 2000). In Berleant's (1991) participatory model there is no difference between the two.

According to Krogh (2008) we also read, revise and constantly resume environment. The ELC defines landscape as an area as perceived by people. If we want to meet the aims of ELC, we should evaluate the landscape based on both conceptions, cognitive and non-cognitive. 
According to Brunetta and Voghera (2008, p. 73) peoples' perception of belonging and cultural identity is central to the notion of the landscape. This can only happen effectively when a group of people recognize and define their specific landscape values in view of natural and human factors and their interaction.

Cultural landscape management requires merging of the views of experts and people. It also offers ways of enhancing participation and environmental engagement. The expert view in our study area, Reykholtsdal's cultural landscape, is based on scientifically validated values. The medieval heritage of poet Snorri Sturluson, original estates and archaeological remainders are the values of the past. Climate change, afforestation, erosion control and population growth are the values of the future.

Practical knowledge (Syse, 2010 p. 479) connected to cultural landscape in Reykholtsdal is based on adaptation and intangible cultural heritage. Settlement and grazing have caused clearance of woods over the centuries. As cultural landscape has evolved, the land was revealed. The folklore is attached to bare land and its characteristic land forms. To an outsider those land forms are just rocks, cliffs and mounds. To local people they can be habitats of hidden people or elves. That invisible landscape affects land use, because it is given to creatures that live in it, not reserved for people. Habitats, or enchanted places, are not sign posted or mapped. They are to be learn about from parents, neighbours or former residents. Merged views would not enhance only holistic approach to landscape, but also a tolerant practise of sharing and creating the landscape.

The question was how peoples' way to read the landscape through folklore affects their way of perceiving and using the landscape. Another question was, can the invisible landscape be found in landscape dynamics.

In Reykholtsdalur, peoples'way of recognizing and defining landscape values intertwines with folklore. Certain landscape features are perceived and understood intuitively as special places. Folklore landscape also steers human land use, because these places are left undisturbed when verified or believed to be enchanted.

To Icelanders the land is a living entity in itself. In folktales landscape features are bubbling with life. Some landscape characters are revered, some are feared. Enchanted landscape is invisible to most of the human eyes, but it can be interpreted and connected to visible landscape through stories and beliefs (Halmundsson \& Halmundsson, 2009 p. 7).

Folklore-based dialogue between people and landscape has sustained through centuries and is still alive among the present generation in the valley of Reykholtsdal. An informant, who is a scientist, explained it as an introduction to the landscape. Through stories about supernatural beings geological formations can be explained in a pedagogical way for example by familiarizing children with landscapes (porgeirsson B., 2009).

We often attach intangible cultural heritage to the changes in the landscape by the action of some cultural group. Different types of cultural heritage features, like churches and industrial buildings, are connotations of social and cultural codes that guide our way to participate in our environment.

In Reykholtsdal intangible cultural heritage is attached to the changes in landscape by the action of nature. Different types of natural features are connotations of enchanted landscape and folklore keeps alive social and cultural codes that guide peoples' way to participate with that special environment.

\section{Discussion}

We need new practices for inventory of perceived landscape, if we want to integrate expert knowledge and local knowledge, and meet the aims of landscape policies set at the ELC. Brunetta and Voghera have emphasised that landscape evaluation which depends on values should pass on to evaluation that constructs values (Brunetta \& Voghera 2008, p. 72-73). Inventories based on a model for landscape comprehension gives us a tool to with which this can be achieved. It enhances local peoples' sense of belonging and cultural identity by making 
it visible and acknowledges and promotes the creation of culturally and socially sustainable landscapes.

In Krogh's model landscape is read through constant perception, cognition and action. The research material collected during the course is narrow of course. Even so, it can be used to illustrate the model when it is used to investigate the landscape comprehension through folklore.

All the informants have existential experience of the landscape in Reykholtsdal. Interviews and photomodelling are a way to explore their landscape perception. Questions about their plans for their own land or plans for the valley as authorities are a way to explore their actions. The following discussion is aims at exploring their cognition. When the interview results are interpreted, the social, cultural, political, historical and professional context of the informants has to be considered reflexively.

Krogh's model for landscape comprehension could answer also to the question of identifying the landscape by recognizing shared landscape values. Values based on "official level" represent random peoples' values, because they are composed from expert data. If the collection of expert data would be based on landscape perception, including practical knowledge, it could lead to identification of shared values, comprehension of commonly valuable landscape features and tolerant evaluation.

Syse (2010, p. 482) has argued for merging the local and expert knowledge through the practise of generating and sharing experiences. Environmental education is a mediator between people, information and landscape. Evaluation and management of cultural landscapes with participatory methods, successfully used in environmental education, can be a way to create multidisciplinary planning.

This sort of planning could integrate local knowledge and expert knowledge, and give space to both expert values and local values. It could help to secure the balance between landscape values and promote the spreading of environmental information.

This could enhance perception of belonging and cultural identity. When people feel that landscapes are a part of their identity and they are culturally attached to it, they want to keep it and pass it on to their children or to the next owner. That is how the use of landscape becomes sustainable, and the landscape becomes heritage.

Selman (2006, p. 22) has argued, that the topic of landscape is moving from sectional to a mainstream feature in spatial planning as reflection of increasing awareness about the needs of sustainable development.

In 2009 The Department for the Built Environment in the Ministry of the Environment in Finland published a guide for composing a cultural environment programme (Lahdenvesi-Korhonen, 2009). It emphasizes the intersectional nature of cultural landscape. But it also highlights the architects and other technical expert in the field of land use planning, when the steering authorities for the programme are introduced. Local people, adults and children, are seen as a resource for data. The evaluation of landscape is seen as an expert task. There is no description about implementing the landscape values of local people into the landscape values of experts. It is neither suggested, that those values could be created together with experts and local people. The programme is suggested to be used in schools and cultural tourism in order to increase the knowledge and appreciation about cultural landscape and cultural heritage in it. But heritage is defined from expert view, usually out of tangible cultural heritage.

The cultural environment programme is meant to be a tool to promote sustainability in the cultural landscape. One could say that ecological and economical sustainability are secured in this process. To implement also social and cultural sustainability into landscape policies in Finland needs further development. The definition of sustainability according the landscape is in move as much as is the topic of landscape. The cultural dimension in sustainable development requires open discussion and research, before it can be properly defined in landscape values and implemented to landscape policies. 
If Krogh's model could be a method for identifying shared landscape values by merging the local and expert knowledge, then deliberative landscape scale planning (Selman, 2006 p. 109-110) could be a method for implementing those values into landscape policies and for deepening human-environment relationship into holistic participation. Deliberative planning recognizes, that cultural landscapes draw their past, present and future meanings from people's relationships to them.

This case study showed that in Iceland people, both lay people and experts, have a way to balance between visible and invisible landscape. The enchanted landscape of folklore is as much in change as is the visible landscape. It re-creates itself when landscape changes, and sometimes it causes the changes in the landscape. The folklore tradition is different in other countries. But the process described in this case is probably quite similar. Photomodelling could be an alternative method to Kaleidoscope model, when we need to see the invisible processes and dynamics in the landscape.

\section{Acknowledgements}

The author gratefully acknowledges the assistance received by supervisor Prof. Dr. Maunu Häyrynen as well as the anonymous reviewers.

References

[1] Aradottir, A. L. (2005). Restoration of birch and willow woodland on eroded areas. Effects of afforestation on ecosystems, landscape and rural development. Proceedings of the AFFORNORD conference, Reykholt, Iceland, June 18-22, 2005. Retrieved from [http://eprints.ulster.ac.uk/14798/1/AFFORNORD_Conference.pdf].

[2] Berleant, A. (1991). Art and Engagement. Philadelphia: Temple University Press.

[3] Brunetta, G. \& Voghera, A. (2008). Evaluating Landscape for Shared values: Tools, $\begin{array}{llll}\text { Principles and Methods. Landscape Reseach, 33(1), } & \text { 71-87. }\end{array}$ DOI: 10.1080/01426390701773839.

[4] Council of Europe (2000). Eurpoean Landscape Convention (Florence convention). Retrieved from [http:// conventions.coe.int/Treaty/en/Treaties/Html/176.htm]

[5] El Harouny, E. (2008). Historiallinen puukaupunki suojelukohteena ja elinympäristönä. Esimerkkeinä Vanha Porvoo ja Vanha Raahe. Oulu: Oulun yliopiston kirjasto. Retrieved from [http://herkules.oulu.fi/isbn9789514289705/].

[6] Haapala, A. (2000). Luonnon kauneus ja rumuus. In Haapala, A. \& Oksanen, M. (Eds.), Arvot ja luonnon arvottaminen. Helsinki: Gaudeamus.

[7] Hall, S. (1996). Introduction: Who needs "Identity"? In Hall, S. \& Du Gay, P. (Eds.), Questions of Cultural identity. London: Sage Publications Ltd.

[8] Hallmundsson, H., Hallmundsson, M. \& Gudjónsson, K. (2009). Icelandic folk and fairy tales. Forlagið.

[9] Krogh, E. \& Clemetsen, M. \& Bischoff, A. \& Jolly, L. \& Skår, M. \& Bjørnstad, K. (2008). Landscape - an Area as perceived by People. Paper submitted for the $23^{\text {rd }}$ Session of PECSRL.

[10] The Permanent European Conference for the Study of the Rural Landscape Lisbon/ Óbidos, Portugal, 1-5 September 2008.

[11] Lahdenvesi-Korhonen, L. (2009). Kulttuuriympäristöohjelma - miksi ja miten. Suomen Ympäristö 10/2009, Helsinki:.Ministry of the Environment.

[12] Mattiucci, C. (2010). A kaleidoscope on ordinary landscapes. The perception of the landscape between the complexity of meaning and operating reduction. Unpublished 
PhD Thesis, University of Trento, Faculty of Engineering. Retrieved from [http://eprintsphd.biblio.unitn.it/348/1/PhD_CristinaMattiucci.pdf].

[13] Pedersen, D. M. (1999). Dimensions of Environmental Competence. Journal of Environmental Psychology 19, 303-308.

[14] Selman, P. (2006). Planning at the landscape Scale. London: Routledge.

[15] Sveinbjarnardóttir, G., Simpson, I. A. \& Thomson, A. M. (2008). Land in Landscapes Circum Landnám: An Integrated Study of Settlements in Reykholtsdalur, Iceland. Journal of the North Atlantic 1, 1-15.

[16] Syse, K. V. L. (2010). Expert Systems, Local Knowledge and Power in Argyll, Scotland. Landscape Research, 35(4), 469-484. DOI: 10.1080/01426397.2010.486855.

[17] UNESCO World Heritage Convention (1972). Retrieved from http://whc.unesco.org/en/conventiontext/.

[18] UNESCO Convention for the Safeguarding of Intangible Cultural Heritage (2003). Retrieved from http://www.unesco.org/culture/ich/index.php?pg=00006.

[19] Wylie, J. (2007). Landscape. London: Routledge.

[20] Aradi, J., Eriksson, C., Palsdottír, A-M., Puolamäki, L. \& Richnau, G. (2009). Disenchantment of the Landscape. The Case of Reykholtsdalur. Ås: UMB.

[21] Emilsdottir, D. (2009). Reception manager and local priest's wife, interviewed $13^{\text {th }}$ of August in Reykholtsdalur.

[22] Gudrádsson, B. (2009). Entrepreneur and farmer, interviewed $14^{\text {th }}$ of August in Reykholtsdalur.

[23] Hallgrímur, J. Ámundason (2009). Verkefnisstjóri at Örnefnasafn, Nafnfræðisvið, at Stofnun Árna Magnússonar, written correspondence with Anna-Maria Palsdottir $13^{\text {th }}$ of August.

[24] Thorgeirsson, B. (2009). Director of Snorrastofa, interviewed $13^{\text {th }}$ of August in Reykholtsdalur. 